\title{
CONCEALED OWNERSHIP OF CONTRACTORS, MANIPULATION OF TENDERS AND THE ALLOCATION OF PUBLIC PROCUREMENT CONTRACTS
}

\author{
Ján Palguta
}

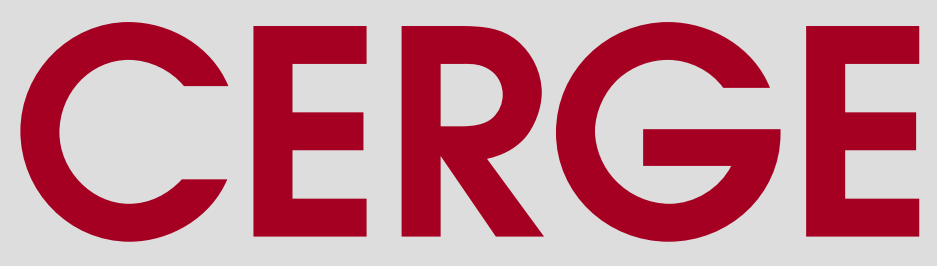




\section{Working Paper Series $\quad 501$ (ISSN 1211-3298)}

\section{Concealed Ownership of Contractors, Manipulation of Tenders and the Allocation of Public Procurement Contracts}

Ján Palguta

CERGE-EI

Prague, January 2014 
ISBN 978-80-7343-305-5 (Univerzita Karlova. Centrum pro ekonomický výzkum a doktorské studium)

ISBN 978-80-7344-298-9 (Akademie věd České republiky. Národohospodářský ústav) 


\title{
Concealed Ownership of Contractors, Manipulation of Tenders and the Allocation of Public Procurement Contracts
}

\author{
Ján Palguta*
}

CERGE-EI ${ }^{\dagger}$

\begin{abstract}
This study provides evidence of a strong link between two channels facilitating rentextraction in public procurement: between concealing the ultimate ownership of contractors and manipulation of the anticipated value of tenders. Using data on more than 15300 tenders awarded to joint-stock companies in the Czech Republic during 2005 - 2010, the study shows that tender value manipulation has been incentivized by the 2006 procurement reform, which established several discontinuities in the anticipated value of tenders. After the reform, manipulation increased much more for tenders awarded to contractors with anonymous owners as opposed to traceable owners. Contractors in manipulated tenders needed to underbid fewer firms in order to win procurements and their winning bids for comparable contracts were, on average, higher than before reform. The results imply disrupted optimality of contractor choice and reduced efficiency of procurement. The results are strongest for contracts on services and construction works, which traditionally conceal rentextraction more easily.
\end{abstract}

Keywords: public procurement, contracts, corruption, rent-seeking, concealed ownership, forensic economics

JEL classification: D72, D73, H72

\footnotetext{
* I would like to thank Randall Filer, Stepan Jurajda, Jan Kmenta and Filip Pertold for insightful comments and helpful suggestions and Jakub Tomisek and Mario Vozar for excellent assistance in data collection. The support from the grant SVV 2014 and the GAUK grant No. 626712 is gratefully acknowledged. All errors in this text are the responsibility of the author.

${ }^{+}$CERGE-El is a joint workplace of Charles University and the Economics Institute of the Academy of Sciences of the Czech Republic. Address: CERGE-EI, PO Box 882, Politických věznů 7, 11121 Prague, Czech Republic. Email: jan.palguta@cerge-ei.cz
} 


\begin{abstract}
Abstrakt
Tato studie dokládá propojení dvou praktik, které usnadňují dolování renty z veřejných zakázek: propojuje anonymizaci konečných vlastníků firem soutěžících o zakázky s manipulacemi odhadované ceny zakázek. Použitím dat o více než 15300 zakázkách, které v České republice v letech 2005 až 2010 vyhrály akciové společnosti, studie prokazuje, že manipulace s cenou zakázek byly vyvolány zavedením nových limitů v odhadované ceně zakázek novelou relevantního zákona z roku 2006. V důsledku této novely vzrostl počet zakázek s odhadovanou cenou nastavenou těsně pod limitem. Tento růst byl rychlejší u tendrů, které vyhrály společnosti s anonymními vlastníky. Vítězové tendrů scenou nastavenou pod limitem museli cenově podlézt méně soutěžních nabídek soupeřících firem, aby vyhráli zakázku, a jejich nabídky se zvýšily oproti stavu před novelou. Výsledky studie naznačují narušení optimality výběru dodavatelů zakázek a pokles efektivnosti jejich zadávání. Výsledky platí obzvlášt́ pro zakázky na služby a stavební práce, které tradičně zakrývají dolování renty snadněji.
\end{abstract}




\section{Introduction}

Reducing rent-seeking in public procurement has the potential to substantially improve public service provision and reduce its costs, particularly in developing and (post-) transition countries, where procurement accounts for a high percentage of the total public expenditure. The impact of reducing rent-seeking in procurement can be substantial, as globally $12-20 \%$ of GDP is redistributed in public procurement markets and in some countries this share can reach as much as 70\% (DAC 2005; OECD 2011).

In order to suppress rent-seeking in procurement, one needs to understand the mechanisms through which rent-seeking occurs and the provisions that allow for it. Unfortunately, scarcity of relevant data and the undercover nature of rent-seeking make the task of measuring its magnitude and identifying its driving factors rather difficult. In light of these difficulties, a new meta-field of academic forensic economics has recently emerged and turned to evaluating hidden illicit behavior, like rent-seeking and corruption, using policy changes (DiTella and Schargrodsky, 2003; Bandiera, Prat and Valletti, 2009), field experiments (Bertrand, Djankov, Hanna and Mullainathan, 2007; Olken, 2007; Ferraz and Finan, 2008) or by looking at discrepancies in large samples of administrative data (Reinikka and Svensson, 2004; Fisman and Wei, 2004, Olken 2006).

This study adopts approaches of academic forensic economics and contributes to the field by analyzing two channels that facilitate rent-seeking in public procurement. In particular, the study shows how manipulations of the anticipated value of tenders and concealment of the identity of the ultimate owners of procurement contractors jointly threaten the optimality of contractor choice and the efficiency of procurement. The two investigated channels lead to provision of preferential access and prices of contracts to companies with concealed owners and concealment of potential conflicts of interest in procurement.

For identification, the study focuses on a procurement reform instituted in 2006 in the Czech Republic. The investigated policy change established several statutory 
thresholds in the anticipated value of procurement tenders. Below the new thresholds, procurement agencies gained the discretion to limit access of potential contractors to procurement competition and to selectively invite potential contractors into the contract-awarding negotiations. The results suggest that via preferential access to contract-awarding negotiations, procurement agencies provided preferential treatment to pre-selected companies.

The study uses data on a universe of more than 1,400 joint-stock companies that won more than 15,300 procurement contracts in 2005-2010 in the Czech Republic. Using this data, the study shows that manipulation of tender value emerged together with the introduction of thresholds and discontinuities in the anticipated value of tenders. Thanks to the possibility of clear-cut labeling of the traceability of contractors' ultimate beneficiaries, the study shows that the increase in manipulations was substantially larger for contracts that were awarded to companies with concealed rather than traceable owners. Contractors of the manipulated tenders needed to underbid fewer competitors in order to win contracts and their winning bids were on average higher than before the reform. The results are particularly strong for contracts on services and construction works, which usually conceal rent-extraction more easily due to their traditionally more hardly measurable (and non-verifiable) attributes.

Broadly, this study relates to the empirical literature that provides evidence of hidden illicit behavior using objective rather than perception-based measures (see, for instance, Reinikka and Svensson, 2004; Bertrand et al. , 2007; Olken, 2007; Fisman and Miguel, 2007; Ferraz and Finan, 2011, as well as other works surveyed by Svensson, 2005 and Zitzewitz, 2011). This study provides evidence of manipulation of procurement tenders and of preferential treatment of companies with concealed owners. It may be among the first to execute such large scale analysis of public procurement in a (post-) transition country.

More specifically, this study contributes to the literature that highlights the role of incentives for hidden illicit behavior (see, for instance, Duggan and Levitt, 2002; Di Tella and Schargrodsky, 2003; Jin and Leslie, 2003; Bandiera, Prat, and Valletti, 2009). It 
examines channels that open up opportunities for rent-seeking in public service provision markets. Both the manipulation of tenders and the preferential treatment of anonymous companies follow the establishment of discontinuities in the anticipated value of tenders. Manipulation and increase in the preferential treatment are largest just below the thresholds, where the returns from illicit behavior are the largest.

This study also relates to other research that focuses on tracing hidden illicit behavior using discontinuous incentives (see, for instance, Wolfers, 2006; McCrary, 2008; Saez, 2010 or Camacho and Conover, 2011). None of these articles, however, analyzes discontinuous incentives at thresholds in public procurement. The only empirical evidence of manipulation of tender value has been provided in the previous work of the author (Palguta, 2013). Yet in the previous work I do not distinguish whether manipulation is driven by corruption of procurement officials or by their lack of skill or motivation to procure efficiently above statutory thresholds. In contrast, this study shows that concealed ownership of contractors and manipulation of contracts combine to facilitate rent-extraction from procurement.

Finally, because the concealment of ultimate beneficiaries of companies corresponds to concealing potential conflict of interests of actors in procurement, this study relates to the large literature that studies connections of firms to politicians or state representatives (for instance, Roberts, 1990; Fisman, 2001; Khwaja and Mian, 2005; Faccio, 2006; Jayachandran, 2006; Goldman, Rocholl and So, 2009). Consistently with this strand of literature, this study demonstrates several advantages to potential (although concealed) connections - for instance, companies with concealed owners enjoy preferential access to contracts and preferential prices of contracts.

The rest of the paper is organized as follows. Section 2 describes the institutional framework of the Czech public procurement and outlines two examined rentextraction channels. Section 3 describes data on procurement contracts and contractors. Section 4 describes the estimation strategy. Section 5 presents the empirical analysis of tender manipulation and performance of anonymous companies in procurement. Section 6 summarizes and provides policy implications. 


\section{Institutional Setting}

\section{Public Procurement and Corruption in the Czech Republic}

Public procurement constitutes one of the largest public spending processes in the Czech Republic. Yearly, about 17\% of GDP (USD 31 billion in 2010) is spent on procurement of supplies, construction work and services - a figure which amounts to the second largest procurement market among OECD34 countries (OECD 2011).

Czech public procurement has been many times strongly linked to favoritism, rentseeking and corruption. In the World Economic Forum (2011) ranking of countries by how common it is for firms to make bribes connected with awarding of public contracts, the Czech Republic ranked $73^{\text {rd }}$ out of 142 countries. In a ranking by the extent to which government officials show favoritism to well-connected firms when deciding upon contracts, the Czech Republic ranked even worse as the $123^{\text {rd }}$ country. In a Corruption Perceptions Index produced by Transparency International (2012), the Czech Republic ranked at the $54^{\text {th }}-57^{\text {th }}$ position.

The size of the public procurement market and the prevalence of bribery and political favoritism in procurement, two factors important for a fair and efficient allocation of governmental contracts, makes the Czech Republic a good candidate to study the nature and consequences of rent-seeking in public procurement.

\section{Concealment of Ultimate Owners of Contractors}

Concealment of the ultimate ownership of companies, the first channel of facilitating illicit rent-extraction in procurement, is a threat to the efficiency and fairness of procurement processes, mainly because anonymity of contractors conceals potential conflicts of interest of agents being both procurement officials and stakeholders in anonymously owned companies. The situation may lead officials to yield to their private interests and to secure preferential treatment for allied companies. Numerous reports conclude that companies whose ultimate beneficiaries are not traceable may engage in undesirable behavior in public contracting (IRS 1981, United Nations 1998, Transcrime 2000, OECD 2001 or Financial Action Task Force 2006.) 
Anonymous ownership is a worldwide phenomenon. Even in developed countries it is feasible to establish a company with untraceable owners with relatively low resources or effort. For example, in the United States, one needs to approach on average 11 legal providers in order to be offered an anonymous shell company without a need to supply any identity documents (Findley, Nielson, and Sharman 2012).

The reason this analysis focuses on anonymously owned companies in the Czech Republic lies in the possibility of clear-cut classification of the (non-)anonymity of locally operating joint-stock companies. The Czech legal code specifically enables the joint-stock companies to issue shares of two types: either they are nominated to concrete holders with shareholders' names directly nominated on shares (or in the list of shareholders) or joint-stock company can issue bearer shares, which entitle any current shares bearer to property rights. The share bearers are not registered anywhere and they are unknown both to the joint-stock company and to any controlling bodies. The change in ownership can be performed instantly without producing any traceable records. The owners of bearer shares usually cash in their benefits from ownership by sending legal representatives to general meetings of jointstock companies.

This institutional setting is ideal for concealing the conflict of interests of actors in procurement and for facilitating rent-extraction in procurement. Even if procurement officials do not initially intend to provide preferential treatment to anonymous firms, a simple untraceable gift of several dozen of anonymous shares may instantaneously create very strong incentives for manipulating the tendering process in favor of a bribing company.

\section{Manipulation of the Anticipated Value of Contracts}

The second channel of facilitating rent-extraction in procurement consists of restricting the procurement competition via manipulations of the anticipated value of tenders. The anticipated value, in general, serves to approximate the expected overall costs that can ensue from fulfilling a procurement contract. Procurement agencies are 
supposed to estimate anticipated value on their own at the beginning of each tendering process. As will be shown, procurement agencies can set anticipated value quite freely and do not face any major consequences from wrongly estimating the anticipated value of contracts.

The anticipated value of tenders remains important, because below certain statutory thresholds (see Table 1) in the anticipated value, the procurement agencies gain the discretion to autonomously select companies which will be invited to participate in contract-awarding negotiations. Above these procurement thresholds the procurement agencies have an obligation to run transparent procurement auctions with open access for bidders. In consequence, a desire for manipulation of anticipated value may arise, so that agencies can avoid the rigid auctions and select companies to be invited into contract-awarding negotiations. For discussion about pros and cons of strict rules in procurement, see Kelman $(1990,2005)$.

Several new procurement thresholds, a central feature of the identification strategy used in this study, appeared in the Czech code due to a procurement reform in 2006. At that time, the reform introduced a new type of contract-awarding procedure into the procurement code, which was bounded by procurement thresholds. The new procedure was supposed to free procurement agencies from rigid rules regulating procurement above thresholds and in exchange it required the procurement agencies to invite five companies of their choice into the contract-awarding negotiations to ensure some competitiveness.

In this setting, however, some firms may have likely started to cooperate with procurement agencies and to manipulate the anticipated value of tenders below thresholds for illicit reciprocal benefits. This way companies could, for example, eliminate their rivals from procurement competitions or obtain other preferential treatment. The discontinuity in the anticipated value provided them with a unique opportunity to influence contractor choice and the efficiency of procurement via manipulations of the anticipated value. 


\section{Data and Descriptive Statistics}

This study uses two primary datasets. The first has detailed information on all procurement contracts awarded in the Czech Republic during 2005 - 2010, and the second has information about numerous characteristics of joint-stock companies that have participated in public procurement within the observation span.

The procurement-level data come from an official database of public procurement contracts. This database is administered by the Czech Ministry of Regional Development, which oversees the procurement process and develops the related legal norms. The dataset is unique in terms of both coverage and detail. Any procurement contract is mandatorily published in the database once its anticipated value exceeds a relevant threshold for small lots (see Table 2). Although procurement agencies can, in addition, voluntarily publish information about smaller contracts in this database, all such information is disregarded from this study, because voluntarily published contracts may be inherently different from the mandatorily published contracts, for instance, in terms of their susceptibility to rent-seeking. For all the mandatorily published contracts, the database includes information on the main subject of contracts, type of procurement agency, type of procurement procedure, number of bids for contracts, value of winning bids and finally, the anticipated value of tenders.

The information in the second dataset comes from the official register of economic subjects administered by the Ministry of Finance of the Czech Republic. It contains information about numerous company characteristics, such as the size of their capital stock, year of incorporation, number of employees, type of control (domestic or foreign), and - most importantly - about the traceability of their shareholders.

The datasets were merged using unique identifiers of contractors, included in them both. The analysis disregards contracts awarded to state institutions, since any contracts between them are unlikely to reflect private rents. In addition, procurement officials may treat state firms differently due to their state ownership. 


\section{Descriptive statistics}

Overall, the procurement database would include information on more than 46,000 mandatorily published contracts worth of 1,043 billion CZK (approximately 52.2 billion USD); however, only the universe of all contracts that were awarded to private jointstock companies is used in this study - for these contracts one can clearly tell whether the contract was awarded to a firm with traceable or anonymous owners. There are more than 15,300 such contracts and their total financial value amounts to 358.5 billion CZK. Of this amount, 20.9 billion CZK worth of contracts was transferred to companies with anonymous shareholders using 1,200 separate procurements. The dataset on company characteristics includes information about 1,411 private jointstock companies, out of which 277 issue bearer shares, which do not allow for traceability of their ultimate owners.

Table 3 provides descriptive statistics of procurement contracts, sorted by their main subject, type of procurement agency and contract-awarding procedure. The descriptive statistics are displayed for anonymous and traceable contractors, separately, while the differences between these groups are tested using one-sample two-group z-tests of equal proportions. The significance levels are displayed in Table 3.

Table 3 shows that conditionally on winning a contract, anonymous companies proportionally won $9.2 \%$ more of contracts on supplies and $8.2 \%$ more of contracts on services. In terms of the value of contracts, anonymous firms won $6.2 \%$ more of contracts on supplies and $14.2 \%$ more of contracts on services. The rest of the contracts were tendered as construction works- anonymous companies therefore won $17.4 \%$ less contracts on construction works in terms of the number of contracts, and $20.3 \%$ less construction contracts in terms of their value.

Regarding the type of procurement agency that companies were successful with, anonymous companies were proportionally $8.4 \%$ more successful with national rather than regional or local agencies in terms of the number of contracts and $4.6 \%$ more successful in terms of contract value. 
Finally, anonymous companies won significantly more often in open tendering procedures $(+3.1 \%$ of contracts), nevertheless, the contracts that they won were smaller in value. The total share of value of procurements obtained in open procedure was $9.7 \%$ smaller for anonymous firms relative to traceable firms. Vice versa, anonymous companies won fewer contracts in simplified negotiations with selective access of bidders (-3.4\% of contracts), yet the size of these contracts must have been on average larger, because the total share of value of procurements in simplified negotiations was the same for both types of companies. Anonymous companies also enjoyed larger contracts in the restricted procurement procedure- they won on average the same share of contracts in this procedure, yet the total share of value of these contracts was $9.6 \%$ larger.

Table 4 provides a more detailed classification of the subject of contracts won by anonymous and traceable companies. The contracts are organized by a CPV code, which is a classification of the main subject of contracts unified across the European Union $^{1}$. According to Table 4, conditional on winning a contract, anonymous companies succeeded much more frequently in tenders on agricultural and forestry services $(+11.2 \%)$, transport equipment and auxiliary products to transportation $(+6.8 \%)$ and much less frequently in contracts on construction works $(-15.5 \%)$ and financial and insurance services (-4.6\%). All these differences are significant at the $1 \%$ level, when tested using one-sample two-group z-tests of equal proportions.

Table 5 finally provides summary statistics of company characteristics. It shows that anonymous companies are significantly smaller firms than traceable companies, both in terms of their average capital stock and number of employees. Anonymous companies are also significantly younger and more often national rather than foreign. A footnote to Table 5 describes the particular statistical tests that were used in order to test the statistical differences between firms.

\footnotetext{
${ }^{1}$ CPV classification unifies the classification of contract subject across EU countries. For more information, visit http://simap.europa.eu/codes-and-nomenclatures/codes-cpv/codes-cpv_en.htm
} 


\section{Empirical Strategy}

This section outlines how the impact of procurement thresholds on manipulation is examined and describes the methodology for testing for preferential treatment of anonymous companies. Preference is examined along two margins: access to contracts and the effective price of contracts.

\section{Impact of Procurement Thresholds on Manipulation}

The key feature of the empirical strategy is that it exploits the timing of the introduction of procurement thresholds into the procurement law. The main identification assumption is that the shape of the density distribution of the anticipated value of contracts would look the same after the 2006 reform as before the reform if the reform did not institute thresholds at specific points in the anticipated value distribution.

The estimation proceeds in two steps. In the first step, all annual histograms of the anticipated value of contracts are plotted with procurement thresholds re-centered to zero. I mark down the height of all histogram bins (an example appears in Figure 1). In the second step, I regress the outcome variable (in this case the bin height), denoted as $Y_{z t}$, on an interaction term between indicator variable for bins located just below thresholds and indicator variable for the validity of the 2006 reform. The interaction term captures the change in the count of contracts below thresholds after the 2006 reform. I include in the model a set of histogram bins fixed effects and time period fixed effects. These capture the level effects of histogram bins and time trend, respectively. The econometric model can be formally expressed as follows:

$$
Y_{z t}=\alpha_{z}+\alpha_{t}+\beta_{1} \text {.Bins_Below_Thresholds }{ }_{z} * 2006 \_ \text {Reform }{ }_{t}+\varepsilon_{z t}
$$

The coefficient of interest $\beta_{1}$ is my estimate of the manipulation of contracts. The null hypothesis is that no change occurred in the count of contracts located just below threshold. 
Whereas the dependent variable is a count variable, I estimate the regression using a Poisson conditional fixed-effects quasi-maximum likelihood (QML). This estimator has several desirable properties, including 1) consistency of the coefficient estimates independently of any assumption on the conditional variance as long as the mean is correctly specified (Wooldridge, 1997), and 2) consistency of the standard errors even if the data generating process is not Poisson. This estimator can be used for nonnegative variables, such as the number of contracts in this case, and fractional variables (Santos Silva and Tenreyro, 2006). The estimation is implemented in STATA with the xtpqml procedure written by Simcoe ${ }^{2}$.

\section{Preferential Access to Contracts}

I use three approaches to inspect preferential access of anonymous firms to contracts. In all of them I exploit the timing of introducing thresholds into the procurement law. Outlining the approaches, one by one, I first essentially repeat the same estimation procedure as in (1), with the difference that I first split the sample into contracts awarded to anonymous firms and traceable firms. I inspect whether anonymous firms experienced the same change in the count of contracts won just below the thresholds as traceable contractors did after the 2006 reform. I also pool the sample again and inspect whether the share of contracts awarded to anonymous firms (out of all contracts) evolved in bins just below thresholds after the reform in the same manner as in other histogram bins. I use the Poisson conditional fixed-effects QML estimator in this first approach.

In the second approach, for each contract I create a binary variable denoting whether the contract was awarded to an anonymously owned contractor or not. I regress this outcome variable on the interaction term between bins located just below thresholds and validity of the 2006 procurement reform, just as before. Because I aim to compare similar contracts before and after the reform, I include in the regressions a set of histogram bins fixed effects and time period fixed effects. Because the outcome variable is a binary variable, I estimate the model using a Probit specification.

\footnotetext{
${ }^{2}$ http://people.bu.edu/tsimcoe/code/xtpqml.txt
} 
In the third approach I again group the contracts into annual histogram bins and I calculate for each bin and year an average number of bids that were submitted in the procurement competition. I regress this outcome variable on the usual set of histogram bin and time period fixed effects and on the interaction term between bins located just below thresholds and validity of the procurement reform. I estimate the regression using Poisson conditional fixed-effects QML estimator.

\section{Preferential Prices of Contracts}

Lastly, I test the hypothesis that anonymous contractors win comparable contracts just below procurement thresholds with higher bids than traceable contractors. For the post-2006-reform period, I use the percentage difference between the value of winning bid and anticipated value of contract (normalized by the anticipated value of contract) as outcome variable, and I regress it on the interaction term between the indicator variable for anonymous contractors and the indicator variable for contracts located just below thresholds. In order to compare comparable contracts, I include into the regression a set of fixed effects for contracts located in the same histogram bins of the anticipated value and indicator variable for anonymous companies. The model can be formally expressed as follows:

$$
Y_{i z}=\alpha_{z}+\text { Anonym }_{i}+\beta_{1} \text {. Contracts_Below_Thresholds }{ }_{z} * \text { Anonym }_{i}+\varepsilon_{i z}
$$

The coefficient of interest $\beta_{1}$ is my estimate of the preferential treatment of anonymous firms. I estimate the regressions using Ordinary Least Squares (OLS) with the standard errors clustered at the histogram bins level. 


\section{Estimation Results}

Table 6 provides evidence of economically and statistically significant manipulation of procurement contracts below procurement thresholds. It shows the results of estimating (1) for groups of contracts on supplies, services, and construction works, respectively. The counts of contracts below thresholds increased after the 2006 reform by $140 \%, 325 \%$, and $160 \%$ for the three main types of the main subject of contracts, respectively. The null hypotheses of no manipulation were rejected with z-statistics of 13.28, 20.13, and 18.19. Technically, the histogram bins of the anticipated value of contracts, which needed to be generated in order to estimate (1), each covered a 250,000 CZK wide interval of anticipated value, starting at thresholds for small lots. The anticipated value interval that defines the contracts "just below procurement thresholds" is 1 histogram bin wide that is 250,000 CZK wide. The results presented in Table 6 are qualitatively in line with the previous estimates of manipulation of tenders (Palguta, 2013). The rest of the results, therefore, utilize the same parametric choice of bin size and width of the interval of "just-below-threshold".

Panels $A$ and $B$ in Table 7 provide evidence of a heterogeneous increase in the manipulation of tenders awarded to anonymous and traceable contractors. For anonymous contractors, panel A shows that bunching of contracts below thresholds increased by $71 \%$ when contracts were on supplies, by $1,115 \%$ in the case of construction works, and contracts on services show virtually an infinite increase in manipulation. For traceable contractors, panel B shows that the bunching of contracts below thresholds increased by $157 \%, 309 \%$, and $141 \%$ for supplies, services, and construction works, respectively. By comparing figures in panels $A$ and $B$, one can conclude that anonymous contractors (relative to traceable contractors) received preferential access to contracts on services and construction works, provided that contracts were located just below thresholds. Manipulation of contract value below thresholds and concealment of the identity of the ultimate owners of contractors, therefore, combine to jointly disrupt the optimality of contractor choice. All estimates in panels $A$ and $B$ are significant at $1 \%$ level. 
Panel $C$ in Table 7 likewise suggests that anonymous contractors (relative to traceable contractors) received more preferential access to contracts on services and construction works located just below thresholds. Panel $\mathrm{C}$ examines the impact of procurement thresholds on the share of contracts awarded to anonymous contractors in particular histogram bins of anticipated value distribution (out of all contracts). In case of services, the increase in the examined share is virtually infinite and for construction works, the share increased by $387 \%$. Both estimates are highly significant at the $1 \%$ level. In case of contracts on supplies, the increase in the examined share is not significantly different from zero.

Table 8 re-interprets the results on preferential access of anonymous contractors to procurement contracts and suggests that contracts manipulations lead to distortions of contractor choice. Table 8 examines the probability that, conditionally on winning a contract, a winning contractor is an anonymously owned company. Table 8 presents the estimates of marginal effects of a probit estimation of (1) with the described conditional probability as the outcome variable. The results suggest that after the 2006 reform, the probability that a contractor in a tender located just below thresholds is anonymous firm increased significantly by $57.3 \%$ and $7.9 \%$ for contracts on services and construction works, respectively. These results are highly significant at the $1 \%$ level. Nonetheless, the results are not valid for contracts on supplies, as Table 8 shows that the same probability decreased after 2006 by $15.5 \%$ for supplies. The estimate is statistically significant at the $1 \%$ level.

Table 9 presents the results of the last measure of access to contracts and shows that after the 2006 reform, contractors in tenders just below thresholds needed to underbid fewer competitors in order to win contracts. The average number of bids on contracts below thresholds diminished by $8.8 \%, 22.12 \%$, and $27.24 \%$ after the 2006 reform for supplies, services, and construction works, respectively. While the estimate for contracts on supplies is significant only at the $10 \%$ level, the other two estimates are significant at the $1 \%$ level. 
Lastly, Table 10 presents evidence of a decrease in the efficiency of procurement due to the preferential treatment of anonymous companies. Table 10 shows the OLS estimates of (2) with the average difference between winning bids and anticipated value of contracts (in percentages of the anticipated value) as the outcome variable. For the post-2006-reform sample and at the $1 \%$ level of significance, I estimate an $8.4 \%$ and $4.8 \%$ increase in the winning bids in tenders on services and construction works, respectively, that were awarded to anonymous contractors just below thresholds. This increase in bids corresponds to a drop in efficiency of procurement. Anonymous companies in comparison to traceable companies were paid a higher price by procurement agencies for fulfilling comparable contracts in the same interval of anticipated value. However, I find no evidence of a similar increase in bids on contracts on supplies.

\section{Conclusion}

The aim of this study was to elaborate on two practices that facilitate rent-extraction in public procurement- particularly, on the anonymity of contractors and manipulation of anticipated value of tenders. I have provided empirical evidence that the two practices complement each other well. I have shown that anonymous firms started to win many more manipulated contracts below procurement thresholds relatively to firms with traceable shareholders after the 2006 procurement reform in the Czech Republic occurred, which incentivized manipulation of tenders. Complementarities between illicit practices were suggestive of malfeasance, especially when we consider that the results were strongest for contracts on services and construction works that are most susceptible to rent-extraction due to hardly measureable and non-verifiable attributes, like quality.

The results of this study do not contradict the notion that another part of the observed manipulation could be attributed to a lack of skill or motivation of procurement officials to apply open auctions above thresholds. This lack of skill or motivation may explain the other part of the observed manipulation of contracts awarded to firms with 
traceable owners. Nonetheless, since I use only one method of labeling suspected companies, I may not identify all undesirable preferential treatment provided to companies associated with manipulations of tender value.

The policy advice for decision makers is straightforward and has been suggested in the Czech Republic numerous times- either force all companies with anonymous shares to get rid them, or prohibit such companies from public contracts. Although this advice may not close other avenues of concealing ownership - such as offshore shell companies, tax havens or nominee accounts - it would make untraceable rentextraction more difficult. The overall effect on the optimality of contractor choice and on the efficiency of procurement may multiply once we consider the indirect effects of increasing trust in the fairness and transparency of the procurement process. For the Czech Republic, where the political elite have long withstood the pressure to ban anonymous ownership, this action might bear much more than a symbolic meaning. 


\section{References}

Bandiera, Oriana, Andrea Prat, and Tommaso Valletti, "Active and Passive Waste in Government Spending: Evidence from a Policy Experiment," American Economic Review, 99 (2009), 1278-1308.

Bertrand, Marianne, Simeon Djankov, Rema Hanna, and Sendhil Mullainathan, "Obtaining a Driver's License in India: An Experimental Approach to Studying Corruption," Quarterly Journal of Economics, 122 (2007): 1639-1676.

Camacho, Adriana, and Emily Conover, "Manipulation of Social Program Eligibility," American Economic Journal: Economic Policy, 3 (2011), 41-65.

Development Assistance Committee, Harmonising Donor Practices for Effective Aid Delivery; Volume 3: Strengthening Procurement Capacities in Developing Countries (Paris, France: Organization for Economic Co-operation and Development, 2005).

Di Tella, Rafael, and Ernesto Schargrodsky, "The Role of Wages and Auditing during a Crackdown on Corruption in the City of Buenos Aires," Journal of Law and Economics,46 (2003), 269-92.

Duggan, Mark, and Steven Levitt, "Winning Isn't Everything: Corruption in Sumo Wrestling," American Economic Review, 92 (2002), 1594-1605.

Faccio, Mara, "Politically Connected Firms," American Economic Review, 96 (2006), 369-86.

Ferraz, Claudio, and Frederico Finan, "Exposing Corrupt Politicians: The Effects of Brazil's Publicly Released Audits on Electoral Outcomes," Quarterly Journal of Economics, 123 (2008), 703-745.

Ferraz, Claudio, and Frederico Finan, "Electoral Accountability and Corruption: Evidence from the Audits of Local Governments," American Economic Review, 101 (2011), 1274-1311.

Financial Action Task Force, The Misuse of Corporate Vehicles, Including Trust and Corporate Service Providers (Paris, France: FATF/OECD, 2006).

Findley, Michael, Daniel Nielson and Jason Sharman, Global Shell Games: Testing Money Launderers' and Terrorist Financiers' Access to Shell Companies (Brisbane, Australia: Griffith University, Centre for Governance and Public Policy, 2012).

Fisman, Raymond, "Estimating the Value of Political Connections," American Economic Review, 91 (2001), 1095-1102. 
Fisman, Raymond, and Shang-Jin Wei, "Tax Rates and Tax Evasion: Evidence from "Missing Imports" in China," Journal of Political Economy, 112 (2004), 471-500.

Fisman, Raymond, and Edward Miguel, "Corruption, Norms, and Legal Enforcement: Evidence from Diplomatic Parking Tickets," Journal of Political Economy, 115 (2007), 1020-1048.

Goldman, Eitan, Jongil So, and Jorg Rocholl, "Politically Connected Boards of Directors and the Allocation of Procurement Contracts," Review of Finance, forthcoming, 2012.

Internal Revenue Service, Tax Havens and their Use by United States Tax Payers: An Overview (Washington, DC: Internal Revenue Service, 1981).

Jayachandran, Seema, "The Jeffords Effect," Journal of Law and Economics, 49 (2006), 397-425.

Jin, Ginger Zhe, and Phillip Leslie, "The Effect of Information on Product Quality: Evidence From Restaurant Hygiene Grade Cards," Quarterly Journal of Economics, 118 (2003), 409-451.

Kelman, Steven, Procurement and Public Management: The Fear of Discretion and the Quality of Public Performance, (The AEI Press, 1990).

Kelman, Steven, Unleashing Change: A Study of Organizational Renewal in Government, (Brookings Institution Press, 2005).

Khwaja, Asim, and Atif Mian, "Do Lenders Favor Politically Connected Firms? Rent Provision in an Emerging Financial Market," Quarterly Journal of Economics, 120(2005), 1371-1411.

McCrary, Justin, "Manipulation of the Running Variable in the Regression Discontinuity Design: A Density Test," Journal of Econometrics, 142 (2008), 698-714.

OECD, Behind the Corporate Veil: Using Corporate Entities for Illicit Purposes (OECD Publishing, 2001).

OECD, Government at a Glance 2011 (OECD Publishing, 2011).

Olken, Ben, "Corruption and the Costs of Redistribution: Micro evidence from Indonesia," Journal of Public Economics, 90 (2006), 853-870.

Olken, Ben, "Monitoring Corruption: Evidence from a Field Experiment in Indonesia," Journal of Political Economy, 115 (2007), 200-249. 
Palguta, Jan, "Nonlinear Incentive Schemes and Corruption in Public Procurement: Evidence from the Czech Republic," CERGE-EI Working Paper Series No. 483, 2013.

Reinikka, Ritva, and Jakob Svensson, "Local Capture: Evidence from a Central Government Transfer Program in Uganda," Quarterly Journal of Economics, 119 (2004), 678-704.

Roberts, Brian, "A Dead Senator Tells No Lies: Seniority and the Distribution of Federal Benefits," American Journal of Political Science, 34(1990), 31-58.

Saez, Emmanuel, "Do Taxpayers Bunch at Kink Points?" American Economic Journal: Economic Policy, 2 (2010), 180-212.

Santos Silva Joao, and Silvana Tenreyro, "The Log of Gravity," The Review of Economics and Statistics 88(2006), 641-658.

Svensson, Jakob, "Eight Questions about Corruption," Journal of Economic Perspectives, 19 (2005), 19-42.

Transcrime, Euroshore: Protecting the EU Financial System from the Exploitation of Financial Centers and Offshore Facilities by Organized Crime. Final Report, (Transcrime, Research Centre on Transnational Crime, University of Trento, 2000).

Transparency International, Corruption Perceptions Index 2012, (Transparency International, 2012).

United Nations Office for Drug Control and Crime Prevention, Financial Havens, Banking Secrecy and Money Laundering (Washington, DC: United Nations, 1998).

Wolfers, Justin, "Point Shaving: Corruption in NCAA Basketball," American Economic Review, 96 (2006), 279-283.

Wooldridge, Jeffrey, "Multiplicative Panel Data Models without the Strict Exogeneity Assumption," Econometric Theory, 13(1997), 667-678.

World Economic Forum, Global Competitiveness Report 2011-2012 (Geneva, Switzerland: World Economic Forum, 2011).

Zitzewitz, Eric, "Forensic Economics," Journal of Economic Literature, 50 (2012), 73169. 


\section{Tables and Figures}

\section{FIGURE 1}

Exemplar Histograms of the Anticipated Value of Tenders around a Procurement Threshold - Before and After the 2006 Reform
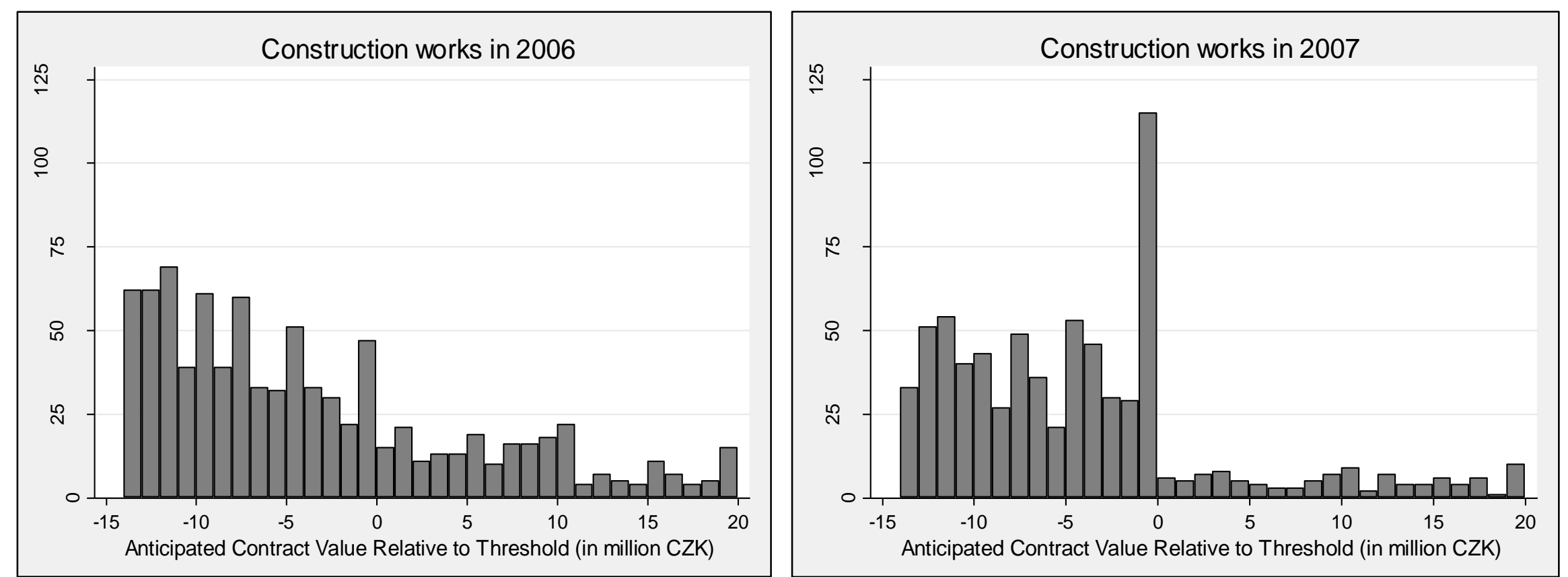

Notes: Figure 1 shows exemplar histograms of the anticipated value of contracts around the statutory threshold for simplified negotiations (re-centered to zero). Construction work contracts awarded to joint-stock companies in 2006 and 2007 are used in order to plot the histograms. Each bar shows a number of contracts awarded to contractors in CZK 1,000,000 bin. The series are trimmed from below by a small lots threshold for construction works and from above by an arbitrary threshold of CZK 40 million. The count of contracts in histogram bins serves as one of measures of access to contracts in particular sections of the anticipated value distribution in the regression analysis. 
TABLE 1

Procurement Thresholds for Simplified Negotiating Procedure (in thousands CZK)

\begin{tabular}{llrrrrrr}
\hline \hline & & 2005 & 2006 & 2007 & 2008 & $\mathbf{2 0 0 9}$ & $\mathbf{2 0 1 0}$ \\
\hline $\begin{array}{l}\text { Supplies and } \\
\text { Services }\end{array}$ & $\begin{array}{l}\text { - National } \\
\text { Agencies }\end{array}$ & N/A & $4290^{*}$ & 4290 & 3782 & 3782 & 3236 \\
& $\begin{array}{l}\text { - Regional } \\
\text { Agencies }\end{array}$ & N/A & $6607^{*}$ & 6607 & 5857 & 5857 & 4997 \\
$\begin{array}{l}\text { Construction } \\
\text { Works }\end{array}$ & & N/A & $20000^{*}$ & 20000 & 20000 & 20000 & 20000 \\
\hline \hline
\end{tabular}

Notes: Table 1 shows the annual procurement thresholds for simplified negotiations categorized by the main subject of contracts and the type of procurement agency (in thousands of (ZKK). Thresholds for simplified negotiations determine the scope of discretion of public officials to invite suppliers of their choice. Thresholds also restrict the entry of bidders and determine the overall transparency of the contract-awarding process. ${ }^{*}$ The introduction of simplified negotiations thresholds occurred on July $1^{\text {st }}$, 2006.

TABLE 2

Procurement Thresholds for Small Lots (in thousands CZK)

\begin{tabular}{lrrrrrr}
\hline \hline & 2005 & 2006 & 2007 & 2008 & 2009 & 2010 \\
\hline $\begin{array}{l}\text { Supplies and } \\
\text { Services }\end{array}$ & 2000 & 2000 & 2000 & 2000 & 2000 & 2000 \\
Construction Works & 2000 & $6000^{*}$ & 6000 & 6000 & 6000 & 6000 \\
\hline
\end{tabular}

Notes: Table 2 shows the annual procurement thresholds for small lots categorized by the main subject of contracts (in thousands of CZK). Procurements below these thresholds are disregarded from the official data-collection. *The change in the small lots threshold for construction works is valid from July $1^{\text {st }}, 2006$. 
TABLE 3

Contract Characteristics, by Company Type

\begin{tabular}{|c|c|c|c|c|c|c|c|c|}
\hline \multirow[b]{2}{*}{ Variable } & \multicolumn{4}{|c|}{ Number of Contracts } & \multicolumn{4}{|c|}{ Value of Contracts } \\
\hline & $\begin{array}{c}\text { All } \\
\text { Firms }\end{array}$ & $\begin{array}{l}\text { Traceable } \\
\text { Firms }\end{array}$ & $\begin{array}{c}\text { Anonymou } \\
\text { s Firms }\end{array}$ & $\begin{array}{c}\text { Difference } \\
\text { (z-test) }\end{array}$ & $\begin{array}{c}\text { All } \\
\text { firms }\end{array}$ & $\begin{array}{l}\text { Traceable } \\
\text { Firms }\end{array}$ & $\begin{array}{l}\text { Anonymous } \\
\text { Firms }\end{array}$ & Difference \\
\hline \multicolumn{9}{|l|}{ Main subject of contracts } \\
\hline - supplies & $18.5 \%$ & $17.8 \%$ & $27.0 \%$ & $+9.2 \% * * *$ & $9.55 \%$ & $9.0 \%$ & $15.2 \%$ & $+6.2 \%$ \\
\hline - services & $27.2 \%$ & $26.6 \%$ & $34.8 \%$ & $+8.2 \% * * *$ & $18.5 \%$ & $18.6 \%$ & $32.8 \%$ & $+14.2 \%$ \\
\hline - construction work & $54.2 \%$ & $55.6 \%$ & $38.2 \%$ & $-17.4 \% * * *$ & $71.9 \%$ & $72.4 \%$ & $52.1 \%$ & $-20.3 \%$ \\
\hline \multicolumn{9}{|l|}{$\begin{array}{l}\text { Type of procurement } \\
\text { agency }\end{array}$} \\
\hline - national & $52.8 \%$ & $52.2 \%$ & $60.6 \%$ & $+8.4 \% * * *$ & $60.0 \%$ & $59.9 \%$ & $64.5 \%$ & $+4.6 \%$ \\
\hline - regional / local & $47.2 \%$ & $47.8 \%$ & $39.4 \%$ & $-8.4 \% * * *$ & $40.0 \%$ & $40.1 \%$ & $35.5 \%$ & $-4.6 \%$ \\
\hline \multicolumn{9}{|l|}{ Type of procedure } \\
\hline - open & $50.4 \%$ & $50.1 \%$ & $53.2 \%$ & $+3.1 \% * *$ & $64.6 \%$ & $65.2 \%$ & $55.5 \%$ & $-9.7 \%$ \\
\hline - restricted & $8.2 \%$ & $8.2 \%$ & $8.1 \%$ & $-0.1 \%$ & $15.8 \%$ & $15.2 \%$ & $24.8 \%$ & $+9.6 \%$ \\
\hline - simplified negotiations & $27.0 \%$ & $27.4 \%$ & $23.0 \%$ & $-3.4 \% * * *$ & $10.4 \%$ & $10.4 \%$ & $10.5 \%$ & $+0.1 \%$ \\
\hline $\begin{array}{l}\text { - negotiations without } \\
\text { prior public notice }\end{array}$ & $14.5 \%$ & $14.4 \%$ & $15.7 \%$ & $+1.3 \%$ & $9.2 \%$ & $9.1 \%$ & $9.2 \%$ & $+0.1 \%$ \\
\hline
\end{tabular}

Notes: Table 3 describes the sample of procurement contracts by their main subject, type of procurement agency and type of procurement procedure. It describes contracts awarded to all companies and to groups of companies with traceable and concealed owners, respectively. The differences in proportions of contracts awarded in particular categories across the two groups are tested using one-sample two-group z-tests of equal proportions. ${ }^{* * *} p<0.01,{ }^{* *} p<0.05,{ }^{*} p<0.1$ 
TABLE 4

Procurement Contracts Sorted According to a Detailed CPV Classification of Subject of Contracts

\begin{tabular}{|c|c|c|c|c|c|}
\hline $\begin{array}{l}\text { CPV } \\
\text { Code }\end{array}$ & Subject of Contract & $\begin{array}{r}\text { All } \\
\text { companies }\end{array}$ & $\begin{array}{r}\text { Traceable } \\
\text { Firms } \\
\end{array}$ & $\begin{array}{r}\text { Anonymous } \\
\text { Firms } \\
\end{array}$ & $\begin{array}{r}\text { Difference } \\
\text { (z-test) }\end{array}$ \\
\hline 45 & Construction works & $51.5 \%$ & $52.7 \%$ & $37.2 \%$ & $-15.5 \% * * *$ \\
\hline 77 & Agricultural services and forestry & $5.5 \%$ & $4.6 \%$ & $15.8 \%$ & $+11.2 \% * * *$ \\
\hline 34 & $\begin{array}{l}\text { Transport equipment and auxiliary products to } \\
\text { transportation }\end{array}$ & $1.9 \%$ & $1.3 \%$ & $8.2 \%$ & $+6.8 \% * * *$ \\
\hline 66 & Financial and insurance services & $4.3 \%$ & $4.7 \%$ & $0.1 \%$ & $-4.6 \% * * *$ \\
\hline 9 & $\begin{array}{l}\text { Petroleum products, fuel, electricity and other } \\
\text { sources of energy }\end{array}$ & $1.0 \%$ & $0.9 \%$ & $2.4 \%$ & $+1.5 \% * * *$ \\
\hline 18 & $\begin{array}{l}\text { Clothing, footwear, luggage articles and } \\
\text { accessories }\end{array}$ & $0.4 \%$ & $0.3 \%$ & $1.8 \%$ & $+1.5 \% * * *$ \\
\hline 24 & Chemical products & $1.7 \%$ & $1.9 \%$ & $0.4 \%$ & $-1.4 \% * * *$ \\
\hline 79 & $\begin{array}{l}\text { Business services: law, marketing, consulting, } \\
\text { recruitment, printing and security }\end{array}$ & $0.8 \%$ & $0.7 \%$ & $2.1 \%$ & $+1.4 \% * * *$ \\
\hline 64 & $\begin{array}{l}\text { Business services: law, marketing, consulting, } \\
\text { recruitment, printing and security }\end{array}$ & $1.2 \%$ & $1.3 \%$ & $0.2 \%$ & $-1.1 \% * * *$ \\
\hline 71 & $\begin{array}{l}\text { Architectural, construction, engineering and } \\
\text { inspection services }\end{array}$ & $2.7 \%$ & $2.8 \%$ & $1.8 \%$ & $-1.1 \% * *$ \\
\hline
\end{tabular}

Notes: Table 4 describes procurement contracts according to their detailed subject. The classification of subject of contracts follows the European Common Procurement Vocabulary (CPV) classification at the level of procurement divisions (first two digits of a CPV code). Figures are shown as percentages of the total number of contracts that firms of a given ownership type won. Figures are shown only for CPV divisions, where the differences between anonymous and traceable contractors are largest. The differences proportions across groups of firms with concealed and traceable owners are tested using one-sample two-group z-tests of equal proportions. $* * * p<0.01, * *$ $p<0.05, * p<0.1$ 


\section{TABLE 5}

Contractors Characteristics, by Type of Ownership

\begin{tabular}{|c|c|c|c|c|}
\hline Variable & $\begin{array}{r}\text { All } \\
\text { companies }\end{array}$ & $\begin{array}{r}\text { Traceable } \\
\text { Firms }\end{array}$ & $\begin{array}{r}\text { Anonymous } \\
\text { Firms }\end{array}$ & Difference \\
\hline Avg. log (capital stock) ${ }^{a}$ & 16.4 & 16.6 & 15.9 & $-0.62 * * *$ \\
\hline (S.D.) & $(2.13)$ & $(2.17)$ & (1.9) & \\
\hline $\begin{array}{l}\text { Median year of } \\
\text { incorporation }^{\text {b }}\end{array}$ & 1997 & 1996 & 1999 & $* * *$ \\
\hline \multicolumn{5}{|l|}{ Number of employees ${ }^{C}$} \\
\hline - 0-24 employees & $29.6 \%$ & $25.9 \%$ & $44.2 \%$ & $+18.4 \% * * *$ \\
\hline - 25 - 99 employees & $33.0 \%$ & $35.2 \%$ & $24.3 \%$ & $-11.0 \% * * *$ \\
\hline - 100 - 249 employees & $16.9 \%$ & $18.4 \%$ & $10.9 \%$ & $-7.5 \% * * *$ \\
\hline - 250-999 employees & $12.5 \%$ & $13.1 \%$ & $10.1 \%$ & $-2.9 \%$ \\
\hline - 1000 and more & $4.0 \%$ & $4.6 \%$ & $1.8 \%$ & $-2.8 \% * *$ \\
\hline - not specified & $4.0 \%$ & $2.9 \%$ & $8.7 \%$ & $+5.8 \% * * *$ \\
\hline \multicolumn{5}{|l|}{ Sector and control $^{\mathrm{c}}$} \\
\hline - nonfinancial national & $79.3 \%$ & $77.4 \%$ & $87.0 \%$ & $+9.6 \% * * *$ \\
\hline - nonfinancial foreign & $18.5 \%$ & $19.9 \%$ & $13.0 \%$ & $-6.8 \% * * *$ \\
\hline - financial companies & $2.2 \%$ & $2.8 \%$ & $0 \%$ & $-2.8 \% * * *$ \\
\hline
\end{tabular}

Notes: Table 5 provides descriptive characteristics of procurement contractors by type of their ownership. The difference between groups of contractors with anonymous and traceable owners is tested using: a) a one-sample two-group t-test in case of the "average log of capital stock"; b) a k-sample test of the equality of medians in case of the median year of incorporation and c) a one-sample two-group z-tests of the equality of proportions in cases of "Number of employees" and "Sector and control". *** $\mathrm{p}<0.01,{ }^{* *} \mathrm{p}<0.05, * \mathrm{p}<0.1$ 


\section{TABLE 6}

The Impact of Thresholds on Manipulation - All Contracts

\begin{tabular}{lccc}
\hline \hline Dependent variable: & \multicolumn{2}{c}{ Number of Contracts in Bin z and Time t } \\
\cline { 2 - 4 } & Supplies & Services & $\begin{array}{c}\text { Construction } \\
\text { Works }\end{array}$ \\
\hline Bins Just Below Thresholds $x$ & $0.876^{* * *}$ & $1.449^{* * *}$ & $0.958^{* * *}$ \\
2006 Reform & {$[0.066]$} & {$[0.072]$} & {$[0.053]$} \\
\hline Histogram Bin Fixed Effects & YES & YES & YES \\
Annual Fixed Effects & YES & YES & YES \\
\hline & & & \\
Number of Observations & 918 & 978 & 816 \\
Number of Clusters & 153 & 163 & 136 \\
\hline \hline
\end{tabular}

Notes: Table 6 reports the estimates of (1) estimated using Poisson conditional fixedeffects QML. The basic unit of observation in all regressions is a histogram bin from the empirical annual distribution of the anticipated value of procurement contracts. The height of the histogram bins, i.e. the number of contracts awarded in each bin in each year serves as the dependent variable and the measure of access of firms to contracts. I regress this measure of access on the interaction term 'Bins Just Below Thresholds $x$ 2006 Reform' between indicator variable for histogram bins located just below thresholds and indicator variable for the validity of the 2006 procurement reform. All regressions include histogram bins fixed effects and time period fixed effects. The coefficient estimates are interpreted as $(\exp (\beta)-1) * 100$ percentage change. Robust standard errors are presented in brackets, ${ }^{* * *} p<0.01,{ }^{* *} p<0.05, * p<0.1$ 
TABLE 7

The Impact of Thresholds on Access to Contracts - By Contractors' Ownership Type

A) Anonymous Contractors

\begin{tabular}{lccc}
\hline Dependent variable: & \multicolumn{3}{c}{ Number of Contracts in Bin z and Time t } \\
\cline { 2 - 4 } & Supplies & Services & Construction \\
\hline Bins Just Below Thresholds $x$ & $0.537^{* * *}$ & $14.022^{* * *}$ & $2.497^{* * *}$ \\
2006 Reform & {$[0.163]$} & {$[1.016]$} & {$[0.146]$} \\
& & & \\
& 414 & 636 & 504 \\
Number of Observations & 69 & 106 & 84 \\
Number of Clusters &
\end{tabular}

B) Traceable Contractors

Dependent variable: $\quad$ Number of Contracts in Bin $\mathbf{z}$ and Time $\mathbf{t}$

\begin{tabular}{lccc} 
& Supplies & Services & Construction \\
\hline Bins Just Below Thresholds $x$ & $0.943^{* * *}$ & $1.408^{* * *}$ & $0.879^{* * *}$
\end{tabular}
2006 Reform

$[0.074]$

[0.051]

\begin{tabular}{|c|c|c|c|}
\hline Number of Observations & 918 & 936 & 804 \\
\hline Number of Clusters & 153 & 156 & 134 \\
\hline \multicolumn{4}{|l|}{ C) All Contractors } \\
\hline \multirow[t]{2}{*}{ Dependent variable: } & \multicolumn{3}{|c|}{$\begin{array}{l}\text { Share of Contracts Awarded to Anonymous } \\
\text { Contractors in Bin } \mathrm{z} \text { and Time } \mathrm{t}\end{array}$} \\
\hline & Supplies & Services & Construction \\
\hline \multirow[t]{2}{*}{$\begin{array}{l}\text { Bins Just Below Thresholds } x \\
2006 \text { Reform }\end{array}$} & -0.295 & $12.335^{* * *}$ & $1.583 * * *$ \\
\hline & [0.211] & [1.023] & [0.207] \\
\hline Number of Observations & 414 & 459 & 481 \\
\hline Number of Clusters & 69 & 58 & 84 \\
\hline
\end{tabular}

Notes: Table 7 reports the estimates of (1) estimated using Poisson conditional fixedeffects QML. The basic unit of observation in all regressions is a histogram bin from the empirical annual distribution of the anticipated value of procurement contracts. In Panels $A$ and $B, I$ use the height of the histogram bins, i.e. the number of contracts awarded in each bin and year as the dependent variable and measure of access to contracts. I regress it on the interaction term 'Bins Just Below Thresholds * 2006 Reform' between indicator variable for histogram bins located just below thresholds and indicator variable for the validity of the 2006 procurement reform. In panel C, I use a share of contracts awarded to anonymous contractors as the dependent variable. All regressions include histogram bins fixed effects and time period fixed effects. Panel $A$ reports the results for firms with anonymous owners. Panel B reports the results for firms with traceable owners. Panel $C$ reports the results for all contractors. The coefficient estimates are interpreted as $(\exp (\beta)-1) * 100$ percentage change. Robust standard errors are presented in brackets, $* * * p<0.01, * * p<0.05, * p<0.1$ 


\section{TABLE 8}

Robustness Checks - The Impact of Thresholds on Contractor Choice

\begin{tabular}{lccc}
\hline Dependent variable: & \multicolumn{2}{c}{$\begin{array}{c}\text { Conditional Probability that a Winning } \\
\text { Contractor was an Anonymous Firm }\end{array}$} \\
\cline { 2 - 4 } & Supplies & Services & $\begin{array}{c}\text { Construction } \\
\text { Works }\end{array}$ \\
\hline Contracts in Bins Just below & $-0.155^{* * *}$ & $0.573^{* * *}$ & $0.079 * * *$ \\
Thresholds x 2006 Reform & {$[0.024]$} & {$[0.041]$} & {$[0.008]$} \\
\hline Histogram Bin Fixed Effects & YES & YES & YES \\
Annual Fixed Effects & YES & YES & YES \\
\hline & & & \\
Number of Observations & 1448 & 2367 & 4775 \\
Number of Clusters & 67 & 99 & 83 \\
\hline \hline
\end{tabular}

Notes: Table 8 reports the estimated marginal effects from a probit estimation of (1), where the dependent variable is a binary variable for whether a contract was won by an anonymous contractor (conditionally on winning a contract). The basic unit of observation is a procurement contract in all regressions. I regress the outcome variable on the interaction term 'Contracts in Bins Just below Thresholds x 2006 Reform' between indicator variable for contracts located just below thresholds and indicator variable for the validity of the 2006 procurement reform. All regressions include histogram bins fixed effects and time period fixed effects. Estimates are interpreted as percentage change. Robust standard errors clustered at the bin level are presented in brackets, ${ }^{* * *} p<0.01, * * p<0.05, * p<0.1$ 


\section{TABLE 9}

Robustness Checks - The Impact of Thresholds on Access to Contracts

\begin{tabular}{lccc}
\hline \hline Dependent Variable: & \multicolumn{2}{c}{$\begin{array}{c}\text { Average Number of Bids for Contracts in bin z } \\
\text { and time } \mathbf{~}\end{array}$} \\
\cline { 2 - 4 } & Supplies & Services & $\begin{array}{c}\text { Construction } \\
\text { Works }\end{array}$ \\
\hline Bins Just Below Thresholds * & $-0.092^{*}$ & $-0.250^{* * *}$ & $-0.318^{* * *}$ \\
2006 Reform & {$[0.048]$} & {$[0.070]$} & {$[0.030]$} \\
& YES & YES & YES \\
Histogram Bin Fixed Effects & YES & YES & YES \\
Annual Fixed Effects & & & \\
\hline & 522 & 614 & 711 \\
Number of Observations & 152 & 164 & 135 \\
Number of Clusters & & & \\
\hline \hline
\end{tabular}

Notes: Table 9 reports the estimates of (1) estimated using the Poisson conditional fixed-effects QML. The basic unit of observation in all regressions is a histogram bin from the empirical distribution of the anticipated value of procurement contracts in one year. I use the average number of bids that competed contracts in one histogram bin as a measure of access to contracts. I regress the dependent variable on the interaction term 'Bins Just Below Thresholds * 2006 Reform' between the indicator variable for histogram bins located just below thresholds and indicator variable for validity of the 2006 procurement reform. All regressions include histogram bins fixed effects and time period fixed effects. The coefficient estimates are interpreted as $(\exp (\beta)-1) * 100$ percentage change. Robust standard errors are presented in brackets, $* * * p<0.01, * * p<0.05, * p<0.1$ 
TABLE 10

The Impact of Preferential Treatment on Contract Price

\begin{tabular}{lccc}
\hline \hline \multirow{2}{*}{ Dependent Variable: } & \multicolumn{2}{c}{$\begin{array}{c}\text { Difference Between Winning Bid and } \\
\text { Anticipated Value (in \% of anticipated value) }\end{array}$} \\
\cline { 2 - 4 } & Supplies & Services & $\begin{array}{c}\text { Construction } \\
\text { Works }\end{array}$ \\
\hline Contracts in Bins Just Below & -0.023 & $0.084^{* * *}$ & $0.048^{* * *}$ \\
Thresholds x Anonymous Firm & {$[0.032]$} & {$[0.024]$} & {$[0.014]$} \\
\hline Anonymous Firm Dummy & YES & YES & YES \\
Histogram Bin Fixed Effects & YES & YES & YES \\
\hline Constant & $-0.083^{* * *}$ & $-0.281^{* * *}$ & $-0.019^{* * *}$ \\
& {$[0.001]$} & {$[0.001]$} & {$[0.001]$} \\
\hline & & & \\
Number of Observations & 1437 & 2143 & 3850 \\
Number of Clusters & 145 & 164 & 134 \\
\hline \hline
\end{tabular}

Notes: Table 10 reports the OLS estimates of (2) for the post 2006 reform period, where I use the difference between the value of winning bids and anticipated value of contracts (calculated in \% of the anticipated value) as the outcome variable. The basic unit of observation here is a procurement contract. I regress the outcome variable on an interaction term 'Contracts in Bins Just Below Thresholds $x$ Anonymous Firm' between an indicator variable for contracts located just below procurement thresholds and indicator variable for anonymous firm being a contractor. All regressions include fixed effects for histogram bins into which the anticipated value of procurement contracts would fall and a dummy variable for anonymous firms being contractors. Estimates are interpreted as percentage changes. Robust standard errors, clustered at the bin level, are presented in brackets, ${ }^{* * *} p<0.01,{ }^{* *} p<0.05, * p<0.1$ 


\section{Working Paper Series}

ISSN 1211-3298

Registration No. (Ministry of Culture): E 19443

Individual researchers, as well as the on-line and printed versions of the CERGE-EI Working Papers (including their dissemination) were supported from institutional support RVO 67985998 from Economics Institute of the ASCR, v. v. i.

Specific research support and/or other grants the researchers/publications benefited from are acknowledged at the beginning of the Paper.

(c) Ján Palguta, 2014

All rights reserved. No part of this publication may be reproduced, stored in a retrieval system or transmitted in any form or by any means, electronic, mechanical or photocopying, recording, or otherwise without the prior permission of the publisher.

Published by

Charles University in Prague, Center for Economic Research and Graduate Education (CERGE) and

Economics Institute of the ASCR, v. v. i. (EI)

CERGE-El, Politických vězňů 7, 11121 Prague 1, tel.: +420 224005 153, Czech Republic.

Printed by CERGE-EI, Prague

Subscription: CERGE-EI homepage: http://www.cerge-ei.cz

Phone: + 420224005153

Email: office@cerge-ei.cz

Web: http://www.cerge-ei.cz

\section{Editor: Marek Kapička}

The paper is available online at http://www.cerge-ei.cz/publications/working_papers/.

ISBN 978-80-7343-305-5 (Univerzita Karlova. Centrum pro ekonomický výzkum a doktorské studium)

ISBN 978-80-7344-298-9 (Akademie věd České republiky. Národohospodářský ústav) 
CERGE-EI

P.O.BOX 882

Politických vězňů 7

11121 Praha 1

Czech Republic http://www.cerge-ei.cz 